\title{
The legacies of slavery in and out of Africa
}

\author{
Graziella Bertocchi
}

\begin{tabular}{l}
\hline Correspondence: \\
graziella.bertocchi@unimore.it \\
Dipartimento di Economia Marco \\
Biagi, University of Modena and \\
Reggio Emilia, CEPR and IZA, Viale \\
Berengario, 51, I-41121 Modena, \\
Italy
\end{tabular}

Correspondence: Biagi, University of Modena and Berengario, 51, l-41121 Modena Italy

\begin{abstract}
The slave trades out of Africa represent one of the most significant forced migration experiences in history. In this paper, I illustrate their long-term consequences on contemporaneous socio-economic outcomes, drawing from my own previous work on the topic and from an extensive review of the available literature. I first consider the influence of the slave trade on the "sending" countries in Africa, with attention to their economic, institutional, demographic, and social implications. Next, I evaluate the consequences of the slave trade on the "receiving" countries in the Americas. Here, I distinguish between the case of Latin America and that of the USA. Overall, I show that the slave trades exert a lasting impact along several contemporaneous socio-economic dimensions and across diverse areas of the world.

JEL Classification: J47, J15, 015, N30, P48, Z10
\end{abstract}

\section{Introduction}

This contribution has been prepared for presentation as the Julian Simon Lecture at the 12th IZA Annual Migration Meeting held in Dakar, Senegal, in April 2015. Just off the coast of Dakar, Gorée Island hosts the House of Slaves, a museum and memorial to the slave trade out of Africa, one of the most significant forced migration experiences in history and the main inspiration for this lecture.

While the slave trades and slavery have long been the object of investigation by historians, a recent stream within the economics literature has focused on its potential long-term consequences on socio-economic outcomes. The aim of this paper is to present my own work and thoughts on this topic, and at the same time to collect a survey of the small but growing related literature.

More broadly speaking, this contribution follows the tradition of Engerman and Sokoloff (1997), Hall and Jones (1999), and Acemoglu et al. (2001), who have searched the fundamental, rather than proximate, factors that have determined socio-economic outcomes, with special attention for the potential role of institutional factors such as those shaping labor markets. My goal is to demonstrate that the institutions that permitted the slave trades and slavery, long after their abolition, are still exerting a profound influence on a variety of contemporaneous outcomes, across very diverse areas of the world.

Partly because empirical investigations on the slave trade require often hard-to-find historical data, partly because research is simply in its infancy, the available literature including my own contributions has not so far been able to cover all the potentially affected geographical regions and all spheres of possible influence in a homogenous fashion. Nevertheless, it is possible to organize a presentation along two main axes.

(C) 2016 The Author(s). Open Access This article is distributed under the terms of the Creative Commons Attribution 4.0 International License (http://creativecommons.org/licenses/by/4.0/), which permits unrestricted use, distribution, and reproduction in any medium, provided you give appropriate credit to the original author(s) and the source, provide a link to the Creative Commons license, and indicate if changes were made. 
First, it is natural to distinguish between the long-lasting influence of the African slave trade for the "sending" countries on the one hand and the "receiving" ones on the other. Second, for each set of countries, it is useful to highlight a number of specific economic, institutional, demographic, and social implications which have attracted the attention of the literature. For a selection of issues, I will present new data elaborations based on datasets collected for my previous work. Since African slavery has represented one of the largest-albeit coerced-migration experiences in history, the paper will also emphasize the link between research on the slave trade and the literature on migration, even though this link is still relatively undeveloped.

The paper is organized as follows. In Section 2, I provide a short history of the African slave trades. In Section 3, I consider their influence on the sending countries in Africa, with attention to its economic, institutional, demographic, and social implications. In Section 4, I evaluate the consequences of the slave trade on the receiving countries, drawing a further distinction between Latin America and the USA. For the latter, I also briefly discuss the subsequent experiences of the Second Middle Passage and of the Great Migration. Section 5 concludes and collects ideas and suggestions for future research.

\section{A brief history of the slave trade}

Over the five centuries running from 1400 to 1900, the slave trade encompassed four distinct waves: the trans-Saharan, Indian Ocean, Red Sea, and trans-Atlantic slave trades. The last one was by far the most significant in terms of volume and duration: over the 1529-1850 period, over 12 million Africans were embarked, mostly along the coasts of West Africa, and forced to undertake the Middle Passage across the Atlantic Ocean (see Berlin 2003 for a historical account, and Eltis et al. 1999 and Curtin 1969 for data). The peak was reached between 1780 and 1790, with 80,000 slaves per year being transported, but the traffic remained very intense during the nineteenth century, when between three and four million people were embarked. Throughout the period, the Portuguese were always at the center of the trade: they were the ones that initiated it and they continued it long after Britain outlawed it in 1807. The involvement of Britain culminated in the eighteenth century. France also had a prominent role, followed by Spain, the Netherlands, and the USA. The decline started after 1807, even though the process was very slow and became significant only after mid-nineteenth century when Brazil joined in. The three other slave trades pre-dated the trans-Atlantic wave and followed different paths: the trans-Saharan trade took people from the subSaharan regions to Northern Africa, while both the Indian Ocean and the Red Sea trades took people from Eastern Africa and delivered them to various parts of Asia. Overall, the volume of these three waves comprised half of that involved in the transAtlantic one. The trans-Atlantic trades are by far the better documented ones, thanks to the Trans Atlantic Slave Trade (TAST) Database (see www.slavevoyages.org and the description in Eltis et al. 1999). Based on these data, Table 1 reports the number of slaves embarked from Africa, by broad embarkation regions and by 100-year periods. West-Central Africa represented the main source, with $45 \%$ of the overall volume. Next came Benin (16\%), Biafra (13\%), the Gold Coast (10\%), and Senegambia (6\%).

Slavery was already present in Africa before the slave trades and in fact continues, in some parts of the continent, to the present day. Europe experienced slavery as well. 
Table 1 Embarked slaves during the trans-Atlantic slave trade

\begin{tabular}{|c|c|c|c|c|c|c|c|c|c|}
\hline & Senegambia & $\begin{array}{l}\text { Sierra } \\
\text { Leone }\end{array}$ & $\begin{array}{l}\text { Windward } \\
\text { Coast }\end{array}$ & $\begin{array}{l}\text { Gold } \\
\text { Coast }\end{array}$ & $\begin{array}{l}\text { Bight of } \\
\text { Benin }\end{array}$ & $\begin{array}{l}\text { Bight of } \\
\text { Biafra }\end{array}$ & $\begin{array}{l}\text { West-Central } \\
\text { Africa }\end{array}$ & $\begin{array}{l}\text { South-East } \\
\text { Africa }\end{array}$ & Totals \\
\hline $\begin{array}{l}1501- \\
1600\end{array}$ & 147,281 & 1405 & 2482 & 0 & 0 & 8459 & 117,878 & 0 & 277,505 \\
\hline $\begin{array}{l}1601- \\
1700\end{array}$ & 136,104 & 6843 & 1350 & 108,679 & 269,812 & 186,322 & $1,134,807$ & 31,715 & $1,875,632$ \\
\hline $\begin{array}{l}1701- \\
1800\end{array}$ & 363,187 & 201,985 & 289,583 & $1,014,529$ & $1,284,585$ & 904,616 & $2,365,204$ & 70,930 & $6,494,619$ \\
\hline $\begin{array}{l}1801- \\
1900\end{array}$ & 108,941 & 178,537 & 43,454 & 86,114 & 444,662 & 495,164 & $2,076,685$ & 440,022 & $3,873,579$ \\
\hline Totals & 755,513 & 388,770 & 336,869 & $1,209,322$ & $1,999,059$ & $1,594,561$ & $5,694,574$ & 542,667 & $12,521,335$ \\
\hline
\end{tabular}

TAST Database-Voyages: http://www.slavevoyages.org/

The Roman Empire was in fact a slave society. However, by 1400, slavery had long disappeared from Europe, which motivated the European search for a supply of forced labor in the African continent. African slaves were collected by kidnapping by other Africans or as the result of local wars among Africans. The captives were then sold to foreign traders, together with gold and ivory, in exchange for imported goods including firearms. The consequent so-called gun-slave cycle fueled the perpetuation of the slave trade for centuries. In turn, the incentive to purchase slaves on the part of the Europeans rested in the need to collect manpower for the expansions of the plantation economies being developed in South and Central America after Columbus, to satisfy the quickly increasing taste in Europe for colonial goods such as tobacco and sugar. Again based on the TAST Database, Table 2 reports the number of slaves disembarked in different regions, by broad disembarkation regions and by 100 -year periods. A comparison with Table 1 reveals that almost two million people were lost during transportation. The main destination was Brazil (45\%), next came the Caribbean (22 and $10 \%$, respectively, for the British and French portions) and the Spanish Americas (12\%). Less than $4 \%$ were taken to North America.

The coerced population movement set into place by the trans-Atlantic slave trade was only the beginning of a very long mobilization process that has not yet stopped. Indeed Berlin (2010) has influentially portrayed the history of people of African descent in the USA as framed by four great migrations. The first was the Middle Passage, which in the course of the sixteenth and seventeenth centuries took people from Africa to North America. During the first half of the nineteenth century, the Second Middle Passage involved the transportation of one million African American slaves from the Atlantic coastal regions to the plantations in the interior. The third migratory round, which was no longer forced by voluntary, witnessed the relocation of six million free people of African descent from the rural South to the Northern cities, starting from 1915 with the Great Migration and continuing until the 1970s. Lastly, between the end of the twentieth and the beginning of the twenty-first centuries, new Global Passages of migrants of African descent arrived in the USA from the regions that had hosted the previous out-of-Africa coerced diasporas, i.e., the Caribbean, Latin America, Africa, and Europe.

\section{The consequences of the slave trade in Africa}

This section is devoted to the long-run consequences of the coerced migration of millions of people from Africa, with a focus on the trans-Atlantic experience. To organize 
Table 2 Disembarked slaves during the trans-Atlantic slave trade

\begin{tabular}{|c|c|c|c|c|c|c|c|c|c|c|}
\hline & Europe & North America & British Caribbean & French Caribbean & Dutch Americas & Danish W. Indies & Spanish Americas & Brazil & Africa & Totals \\
\hline $1501-1600$ & 640 & 0 & 0 & 0 & 0 & 0 & 169,370 & 29,275 & 0 & 199,285 \\
\hline 1601-1700 & 2981 & 15,147 & 310,477 & 38,685 & 124,158 & 18,146 & 225,504 & 784,457 & 3122 & $1,522,677$ \\
\hline 1701-1800 & 5240 & 295,482 & $1,813,323$ & 995,133 & 295,215 & 68,608 & 145,533 & $1,989,017$ & 2317 & $5,609,868$ \\
\hline 1801-1900 & 0 & 78,117 & 194,452 & 86,397 & 25,355 & 22,244 & 752,505 & $2,061,625$ & 150,130 & $3,370,825$ \\
\hline Totals & 8861 & 388,746 & $2,318,252$ & $1,120,215$ & 444,728 & 108,998 & $1,292,912$ & $4,864,374$ & 155,569 & $10,702,655$ \\
\hline
\end{tabular}


the presentation, I first look at the impact on local economic development and institutions. The second sub-section turns to the influence on demographics, family structure, and gender roles.

\subsection{The impact on economic development and institutions}

A first wave of research on the influence of history on African economic and institutional development has focused on the colonial period (e.g., Acemoglu et al. 2001, Bertocchi and Canova 2002, and Bertocchi 2011). The long-term implications of precolonial institutions in Africa have been discussed among others by Manning (1990), Herbst (2000), Bockstette et al. (2002), Gennaioli and Rainer (2007), and Michalopoulos and Papaioannou (2013).

A new research line initiated by Nunn (2008a) has instead concentrated on the slave trade period. Nunn (2008a) presents a systematic empirical analysis of the effects of the slave trades on current economic performance. His first contribution is a database reporting estimates of the number of slaves exported from each contemporary African country in each century from 1400 to 1900 . The estimates, which are based on shipping records including the TAST Database (Eltis et al. 1999) and a variety of historical sources, also report the ethnic identity of slaves. The second contribution is to show a robust negative relationship between the number of slaves exported from a country and per capita income in 2000, despite evidence that the slave trades were more intense in the most developed and most densely populated areas in Africa. Through two-stage least-square estimation (where the sailing distances from each country to the nearest locations of demand for slaves are employed as instruments), he can also establish that this relationship is causal. Moreover, he suggests that the channels behind the observed relationship have to be found in the fact that the slave trades impeded the formation of broader ethnic identities. By stopping the homogenization of ethnic differences, they lead to fractionalization and weak and fragmented political structures. The impact of the slave trade on ethnic stratification has also been studied by Whatley and Gillezeau (2011), who establish the existence of a positive relationship between current ethnic fragmentation and slave exports from West Africa.

Following the lead of Nunn (2008a), several authors have further explored the longterm influence of the slave trades along a number of dimensions. Nunn and Wantchekon (2011) investigate the link between the slave trades and trust. Given the importance of trust for economic and institutional development, it may well be the case that it is through this channel that the slave trade still exerts its influence today. The hypothesis is that the slave trades may have generated a culture of mistrust, because of the way slaves were captured by other Africans through raids involving neighboring communities, thus breaking the social bonds upon which trust is built. The hypothesis is tested over the data by Nunn (2008a) on the number of slaves by ethnic group and contemporaneous survey data by Afrobarometer providing measures of trust. They find a robust negative link between slave trades and trust, i.e., individuals whose ancestors were more exposed to the slave trade are today less trusting. Historic distance from the coast is employed as an instrument for the slave trades to perform two-stage least-square estimation indicating that this link is indeed causal. The authors investigate two potential channels of transmission, culture and institutions. The former runs through the diffusion of cultural norms, 
beliefs, and values founded on distrust, the latter through the weakening of trustenforcing institutions. They conclude that both channels are at work but that the former is much stronger than the second.

Again using the data by Nunn (2008a) and Nunn and Wantchekon (2011) combined with the Afrobarometer surveys, in Bertocchi et al. (2015) my coauthors and I examine the relationship between trust and attitudes toward citizenship acquisition. We find that individuals who are more trusting show more positive attitudes toward the acquisition of citizenship by migrants, both at birth and by naturalization (see Bertocchi and Strozzi 2010, 2008 on the link between citizenship laws and migration). These findings are consistent with the hypothesis that the slave trade generated a culture of mistrust that increased the incentive to distinguish insiders from outsiders, with implications for the shaping of immigration policies in contemporary Africa.

The implications of the slave trade can also be shaped by its interaction with geography and the climate. Nunn and Puga (2012) look at the interaction between ruggedness and the effects of the slave trades on current development. Ruggedness can represent a protection from slave raids despite its simultaneous negative effect on trade and economic activity. They find that a beneficial effect of rugged terrain is only present in the African continent and can therefore be explained by the history of slavery. More broadly, these results suggest that geography can affect development through its interaction with past historical events. Fenske and Kala (2015) examine the interaction between the slave trade and climate. They compile a yearly panel of temperatures and slave exports and find that the latter declined in warmer years, which can be explained by the positive association between temperature and mortality and the negative association between temperature and agricultural productivity. In turn cold weather-which reduced participation in the slave trade-predicts higher economic activity in contemporary Africa.

Turning to the impact of the slave trade on political institutions, Whatley (2012a) focuses on political authority in West Africa using data from the Ethnographic Atlas (Murdock 1967) and finds that, in the pre-colonial era, the trans-Atlantic slave trade increased absolutism and reduced democracy and liberalism. This negative influence on West-African political institutions persisted past the colonial era. In particular, he shows that British colonies that exported more slaves were subject to a larger degree to indirect rule. In turn, under indirect rule the colonial administration relied more heavily on local absolutisms as a means of control. Absolutist political customs developed into the rule of law, persisted to post-colonial days, and can still explain state failure in the African continent (see Bertocchi and Guerzoni 2011, 2012 on the determinants and consequences of state fragility in contemporary Africa).

While the consequences of the slave trade are received increasing attention within the economics literature, still scarce attention has been paid to the determinants of the slave trade itself. One exception is Whatley (2012b), who looks at the causes of the expansion in the trans-Atlantic slave trade during the eighteenth century. While the trans-Atlantic slave trade lasted over 400 years, a rapid, five-fold growth episode in fact occurred in the eighteenth century. He combines data from the TA Database and the Anglo-African Trade Statistics (Johnson et al. 1990) to build a time series of annual observations on the British slave trade that spans the period 1699-1807, i.e., until the abolition of the slave trade by Britain. For the first part of the century, he finds 
evidence of a gun-slave cycle, suggesting that African people were enslaved by other Africans and traded in exchange of firearms, which in turn sustained internal wars. These findings confirm the British abolitionists' claim that the slave trades caused African conflict rather than the opposite.

A paper by Fenske and Kala (2014) focuses instead on the consequences of British abolition. The authors argue that abolition increased the incidence of conflict in the areas within Africa affected by the slave trade. Using geo-coded data on conflicts, they show a discontinuous increase after 1807, which occurred both in West Africa, where the slave trade declined, and West-Central and South-East Africa, where the trade increased as a result. They interpret these findings as follows. In West Africa, the decline of the slave trade challenged pre-existing political authorities who defended their interests through violence. In the other regions, enslavement intensified and was often achieved through violent means. The persistent effect of abolition translates in harsher conflict today in the regions where slave exports increased after 1807.

\subsection{The impact on demographics, family structure, and gender roles}

Even though to separate the existing contributions on the slave trade in Africa according to the chosen two sub-sections is somewhat arbitrary, it makes it easier to identify and describe a parallel line of research that starts with Fage (1980), Thornton (1980), and Manning (1981), who highlight the implications of the slave trade for population growth in Africa (see also Manning 2010 and Frankema and Jerven 2014, for more recent projections). As a result of the enslavement and shipping of captives, among whom men often outnumbered women, population declined and the gender balance was distorted. As a result in 1850, Africa had a population of about 50 million, while the level it would have reached in the absence of the slave trades was estimated to be 100 million: thus, the continent lost to the slave trades half of its population. The unbalanced sex ratio provoked a further reduction of population growth, with implications for family structure and male-female relations. Polygyny spread, while matrilinearity weakened. Classic references on the African family structure, from an anthropological and historical perspective, include Boserup (1970), Goody (1973), and Todd (1984), who describe the conditions that, long before the slave trades, determined the diffusion of polygyny in Africa, due to agricultural conditions which made female labor valuable. The diffusion of polygyny in Africa was reinforced by the slave trade, because of male scarcity and the simultaneous need to sustain reproduction rates.

The connection between the slave trade and contemporaneous polygyny is investigated by several related studies. Dalton and Leung (2014) combine the historical data on the slave trades from Nunn (2008a) and Nunn and Wantchekon (2011) with contemporaneous polygyny data from the female Demographic and Health Surveys (DHS). They show that the higher polygyny rates in Western Africa, if compared to Eastern Africa, can be explained by the slave trades, since the preference for male slaves was a distinctive feature of the trans-Atlantic trade out of Western Africa, while the opposite occurred for the Indian Ocean and Red Sea trades out of Eastern Africa. These results are robust to controls for age, religion, urban location, education, and wealth, as well as to instrumental variables estimation. Edlund and $\mathrm{Ku}(2011)$ stress that polygyny in subSaharan Africa is characterized by late but universal marriage for men (general 
polygyny), which differs from the case where only high-quality men obtain more wives thus leaving lower-quality men unmarried. While the latter form of polygyny tends to be driven by inequality, they confirm that general polygyny is linked to the slave trade. Their measure of polygyny is based on United Nations data on the number of married women over the number of married men (for 15 to 49 years old). Within a broad analysis of the determinants of African polygyny, Fenske (2013) uses the DHS householdlevel codification and confirms the existence of a link with the slave trades, albeit with the warning that the latter can only predict polygamy across broad regions, i.e., West Africa against the rest of the continent.

In Bertocchi and Dimico (2015), my coauthor and I build on the relationship between the trans-Atlantic slave trade (from the Nunn and Wantchekon 2011 dataset) and contemporaneous polygyny, which is confirmed across the household, male, and female DHS samples. In particular, we employ a proxy for the intensity of the slave trades represented by the implied, negative demographic shock, since data on population growth present the advantage of being available at a finer, district level.

Using the dataset compiled for Bertocchi and Dimico (2015), based on the household sample, in Table 3, I run a simple bivariate regression where polygyny enters as the dependent variable while the trans-Atlantic slave trade enters as the regressor. The highly significant and positive coefficient illustrates the strong link between the two variables.

In Bertocchi and Dimico (2015), we further extend the analysis of the influence of the slave trade by looking at sexual behavior and HIV infection. What is peculiar about sub-Saharan Africa is that HIV incidence is much more common among women, particularly younger ones. Violence against women, poor health services, lack of education, and unsafe sexual behavior are commonly suggested in order to explain these facts. The paper starts by showing that, throughout sub-Saharan Africa, the slave trades are associated with a negative demographic shock. Next it shows that polygyny is strongly associated with higher HIV infection rates. To establish the causal nexus running from polygyny to HIV infection, the demographic shock following the slave trade is used as an instrument for polygyny. The paper also investigates the underlying transmission channel, by arguing that polygyny is associated with unsatisfying marital relationships, particularly for the women involved. As a consequence, women tend to be more prone to extramarital partnerships. Since promiscuous sexual habits represent one of the main channels of transmission of HIV, there should then be an association between the prevalence of polygyny and the risk of infection. This effect is reinforced by co-wives cohabitation, since the presence of several women

Table 3 The slave trade and polygyny in Africa

\begin{tabular}{ll}
\hline Estimation method: OLS & Dependent variable: polygyny \\
\hline Trans-Atlantic slave trade $(\log (1+x))$ & $0.0233^{* * *}$ \\
& $(0.0059)$ \\
Observations & 195,758 \\
RMSE & 0.400 \\
Sample & Households \\
\hline
\end{tabular}

Robust $t$ statistics in parentheses. The source of the dataset is Bertocchi and Dimico (2015) ${ }^{* * *} p<0.01$ 
sharing the same roof with a single husband exerts a multiplying influence on exposure. The above hypothesis is tested using DHS indicators of sexual behavior. Sexual activity, measured as the likelihood that an individual had sexual activity within the last 4 weeks, is confirmed as being positively associated with infection rates. Female infidelity, measured with the number of extramarital partners within the last 12 months, is also strongly connected with HIV. To establish causality, the paper again relies on the link between the demographic shock that followed the slave trade and sexual behavior, thus uncovering a sort of primordial risk factor for HIV which finds its roots in the slave trade epoch.

Again using DHS data, another related contribution by Teso (2014) turns the attention on the influence of the trans-Atlantic slave trade on gender roles. He argues that the unbalanced sex ratios determined by the enslavement of men pushed women into the labor force and changed their role in the labor market by altering the division of labor in society. He uses the data from Nunn and Wantchekon (2011) on the number of slaves by ethnicity and matches them with DHS data on employment status, women's participation in household decisions, and attitudes toward domestic violence, as well as with Afrobarometer data on opinions about women in politics. He shows that ethnic groups that were more severely affected by the trans-Atlantic slave trade are today more likely to exhibit higher female labor force participation and more equal gender-role attitudes.

\section{The consequences of the slave trade outside Africa}

This section is devoted to the influence of African slavery outside of Africa, with a focus on the trans-Atlantic experience and thus on New World economies. The impact of the influx of slaves from Africa on the countries in the Americas has been emphasized in seminal work by Engerman and Sokoloff (1997), who argue that differences in factor endowments implied differences in the reliance on slave labor, with dramatic consequences for the degree of inequality. Extreme historical inequalitie$\mathrm{s}$-in wealth, human capital, and political power-then exerted a permanent influence on economic development, since they favored the endogenous formation of institutional structures that, rather than promoting growth, maintained the privileges of the elites against the interests of the masses. Nunn (2008b) tests the Engerman-Sokoloff hypothesis in two settings: across 29 former New World countries and across US counties and states. In both settings, he finds a negative impact of past slavery on current development (even though this impact is not driven by plantation slavery). $\mathrm{He}$ also investigates whether inequality is the channel through which slavery adversely affects current performances, but he finds no support for this mechanism. Over a world-wide sample of 46 countries including also North-African and SouthernEuropean recipients of African slaves, Soares et al. (2012) find a significant correlation between past slavery and current levels of inequality. The economics of labor coercion from the perspective of productive efficiency is modeled by Lagerlöf (2009) and Acemoglu and Wolitzky (2011). Apart from the exceptions just mentioned, most of the research on the long-term effects of African slavery has focused on individual countries. In the first sub-section below, I report evidence on Latin America and the Caribbean, while the subsequent sub-section covers the USA. 


\subsection{Latin America and the Caribbean}

The Eastern coast of Latin America and the Caribbean by far received the largest share of African slaves, albeit with marked cross-country heterogeneities. As shown in Table 2, the highest number of slaves was transported to Brazil and the Caribbean (particularly Haiti and Jamaica), while other countries, such as Bolivia, hardly received any. Since this area is currently characterized by deep inequalities, past slavery is a candidate explanation that deserves close attention.

Drawing on Bertocchi (2015), I will start with Brazil, which was the destination of almost half of the African slaves shipped across the Atlantic, ten times the number of those sent to today's USA. Brazil was also the last country in the Americas to abolish slavery in 1888. On the other hand, for centuries Brazil witnessed the coexistence of free and enslaved blacks: at the end of the eighteenth century, $25 \%$ of the blacks were already free. At the same time, the local elites encouraged the formation of a sort of class division among blacks, used as a means to divide and control a huge and thus potentially dangerous black population, which represented $50 \%$ of the total in 1822 . However, because of high mortality and low fertility, the slave population declined very quickly after the end of the trades in the central years of the nineteenth century, while at the same time the flow of European immigrants was fast growing. As a result, by the time slavery was abolished in 1888, slaves were only $5 \%$ of the Brazilian population. Together with the custom of inter-racial marriage, these demographic dynamics can explain why in this country slavery never produced the forms of segregation observed, for instance, in the USA. The empirical evidence on Brazil brings mixed results. Within a county-level analysis of the state of São Paulo, the largest in the country, Summerhill (2010) finds that the intensity of slavery has a negligible effect on income in 2000. Moreover, a measure of agricultural inequality for 1905 exerts no negative influence on long-term development. He therefore concludes that neither slavery nor historical inequality have a discernable economic effect in the long run. However, a negative influence of past slavery emerges in other studies that concentrate on human capital formation. Across Brazilian federal units, Wegenast (2010) uncovers a negative correlation between past land inequality, which was strongly correlated with the presence of crops suitable for the use of slave labor and thus with slavery, and quantitative and qualitative measures of contemporary education, such as secondary school attendance in 2000 and school quality in 2005. In the latifundia system based on slave labor, landlords historically had no incentive to develop mass educational institutions, and this attitude persisted even after abolition in 1888, with consequences still visible today. Similarly, Musacchio et al. (2014) show that over the 1889-1930 period Brazilian states with a lower intensity of slavery were able to exploit positive trade shocks and invest the resulting export tax revenues in elementary education expenditures. The opposite occurs in states with more slaves. The effects persist on the contemporary distribution of human capital.

For the case of Colombia, Acemoglu et al. (2012) investigate the impact of slavery on long-run development by exploiting the variation in the presence of gold mines in different municipalities, since gold mining was strongly associated with demand for slave labor. The empirical findings show that the historical presence of slavery is associated with higher poverty, land inequality, and black population shares, and with lower school enrollment and vaccination coverage. For Puerto Rico, Bobonis and Morrow 
(2014) report evidence on the impact of the libreta system, a local form of labor coercion introduced in 1849 after an agreement between Spain and Britain to enforce the abolition of the slave trade. The libreta de facto replaced slavery and remained in place until 1874. By exploiting variation in the suitability of coffee cultivation and changes in world coffee prices, they estimate how the response of schooling to coffee price changes across municipalities. They find that coercion depresses the effective wages of unskilled labor, inducing more schooling than in the case without coercion. In other words, the abolition of forced labor reduced the incentive to accumulate human capital, consistently with the fact that abolition increased the relative wages of unskilled laborers. Incidentally, parallel evidence of the effect of the enslavement of the American indigenous population is provided by Dell (2010), who examines a region within modern-day Peru that experienced another form of labor coercion, the mining mita. The effects of the mita are detrimental for current household consumption and children's growth, while its influence on education has faded over time.

In summary, the available evidence points to heterogeneous effects of slavery on long-term development. These mixed results may be due to the confounding influence of other interacting factors common to the South-Central America experience, such as the generally slow expansion of mass education, irrespectively of race (see Mariscal and Sokoloff 2000) and a culture of assimilation favoring integration and racial mixing.

\subsection{The USA}

Slavery was introduced in the territories that today represent the USA in the sixteenth century, much later than in Spanish South America and Brazil. The scope was to replace European and African indentured servants as the main source of plantation labor, at the time mostly employed for the cultivation of rice and tobacco. Between 1675 and 1695, the import expanded rapidly. By the 1720s, Virginia and Maryland had been transformed into slave societies. Overall, the inflow to the USA, throughout the next centuries, amounted to an estimated 645,000 slaves, brought in mostly from Africa. The slaves were initially disembarked along the Atlantic coast and forcibly settled in the coastal Southern colonies. Even though the USA absorbed less than $4 \%$ of the entire volume of the trans-Atlantic trade, the local reproduction rate was much higher than elsewhere so that the slave population, unlike in the rest of the Americas, expanded. By the 1730s, births to slave women outnumbered import, with an increase of the African population at an annual rate of $3 \%$. As a result, at the start of the American Revolution, the region was no longer an immigrant society. Later on, in the 1789-1860 period between the Revolution and the Civil War, most slaves were relocated in the inland regions where the plantation economy was quickly expanding following the booming international demand for cotton. This Second Middle Passage ended only with the Confederate defeat in the Civil War. Despite the fact that the Revolution broke the coincidence between blackness and slavery, between 1800 and 1860 the slave population increased from one to four million, so that by the 1860 census the USA had a slave population of about $13 \%$ of the total, distributed within 15 slave states, mostly belonging to the South. The American Civil War led to the abolition of slavery in 1865. The Reconstruction period, running from 1865 to 1877, witnessed a transformation of Southern society and the enactment of legislation 
favoring the rights of former slaves. However, soon afterwards the white elites were able to restore their control and to introduce restrictive Black Codes and disfranchisement provisions. The next massive movement of the African American population occurred between 1916 and 1930, with the so-called Great Migration from the rural South to the urban North, pulled by new job opportunities in the Northern cities and pushed by the crisis of the cotton economy. The latter was caused by the boll weevil beetle infestation and also by the social and political conditions of blacks in the South. Black emigration from the South slowed down after 1930 but picked up again after World War Two. It continued at differentiated speeds until the 1970s, reaching a total volume of six million, with a partial reversal after that.

Early contributions on the economic impact of slavery in the USA include the influential although controversial book by the economic historians Fogel and Engerman (1974), where they argue that slavery in the antebellum South was an efficient production arrangement. Contrasting views were expressed among others by David and Stampp (1976) and Ransom and Sutch (2001). The more recent literature I focus on has investigated the long-term consequences of slavery on development. Across states over the 1880-1980 period, Mitchener and McLean (2003) find a negative and persistent effect on productivity levels. Lagerlöf (2005) explores the link between geography and slavery and also uncovers a negative relationship between slavery and current income. Both across states and counties, Nunn (2008b) reports a negative effect of slavery on per capita income in 2000.

Using the dataset collected by Bertocchi and Dimico (2010), in Table 4 I provide empirical evidence on the cross-county influence of slavery on the contemporaneous level of development in the USA. Slavery is measured as the share of slaves to the total population in 1860, while the dependent variable is per capita income in different years. After entering geographical controls meant to capture structural differences among different regions of the USA (i.e., dummies for counties within former slave states and for counties within North-Eastern and South-Atlantic states), the relationship is not significant for per capita income in 2000. Across previous decades, the relationship was still significant in 1970, but no longer so in 1980 and 1990. This suggests that the effect of slavery on income is not a robust one.

Turning to the link between slavery and current inequality, in Table 5 I present results for different indicators, all measured in year 2000: income inequality and racial inequality (both computed as Gini indexes) and the fraction of the population below the poverty level. Using the same specification as in Table 4, i.e., controlling for structural differences across regions, for all dependent variables, slavery always retains

Table 4 Slavery and income per capita, USA, 1970 to 2000

\begin{tabular}{lllll}
\hline Estimation method: OLS & \multicolumn{4}{l}{ Dependent variable: per capita income } \\
\cline { 2 - 5 } & 2000 & 1990 & 1980 & 1970 \\
\hline Slaves/population 1860 & -0.0249 & -0.0335 & -0.0418 & $-0.134^{* * *}$ \\
& $(-0.79)$ & $(-1.12)$ & $(-1.25)$ & $(-4.34)$ \\
Observations & 1960 & 1960 & 1959 & 1959 \\
$R$-squared & 0.21 & 0.27 & 0.26 & 0.39 \\
\hline
\end{tabular}

Robust $t$ statistics in parentheses. Additional controls: population density in 1860, dummies for North East, South Atlantic, and slave states. The source of the dataset is Bertocchi and Dimico (2010) ${ }^{* * *} p<0.01$ 
Table 5 Slavery and measures of inequality, USA, 2000

\begin{tabular}{llll}
\hline Estimation method: OLS & \multicolumn{2}{l}{ Dependent variables } \\
\cline { 2 - 4 } & Income inequality & Racial inequality & Population below poverty \\
\hline Slaves/population 1860 & $0.0374^{* * *}$ & $0.178^{* * *}$ & $0.0575^{* * *}$ \\
& $(7.42)$ & $(26.33)$ & $(6.40)$ \\
Observations & 1984 & 1984 & 1984 \\
R-squared & 0.31 & 0.40 & 0.32 \\
\hline
\end{tabular}

Robust $t$ statistics in parentheses. Additional controls: population density in 1860, dummies for North East, South Atlantic, and slave states. The source of the dataset is Bertocchi and Dimico (2010) *** $p<0.01$

a positive and significant coefficient. Thus, there is robust evidence that the distribution of per capita income is more unequal today in counties associated in the past with a larger proportion of slaves in the population, and so is the racial dimension of inequality, while poverty is more widespread.

Furthermore, over a state-level panel dataset of educational attainment across races over the 1940-2000 period collected by Bertocchi and Dimico (2010), in Table 6 I regress the educational racial gap, at the high-school and bachelor level, on the share of slaves in the population in 1860: the coefficient is significantly positive, which suggests that the impact of slavery may run through the evolution of the educational gap (Table 6). Indeed, after the Civil War and abolition, illiteracy was predominant among blacks and progress was very slow until the eve of World War Two.

The hypothesis according to which human capital formation may represent the channel through which the effect of slavery still lingers on in American society echoes of a large literature on race and human capital including Smith (1984), Margo (1990), Sacerdote (2005), and Canaday and Tamura (2009). The same hypothesis is further developed and tested in Bertocchi and Dimico (2014), where my coauthor and I employ a Theil decomposition to disentangle the two components of income inequality: inequality across races (racial inequality) and inequality within races (within inequality). The negative and significant influence of slavery is confirmed after controlling for factor endowments and running two-stage least-square regressions. An alternative hypothesis might attribute the effect of slavery on current inequality to racial discrimination. Indeed the bond between slavery and racism, which was non associated with slavery in the Old World and is much weaker in today's Latin America, is perceived as particularly strong in the USA. To test this additional hypothesis, we create a measure of racial discrimination based on returns to skills, estimate returns to education for blacks and whites, and compute the ratio of average returns for blacks to average

Table 6 Slavery and the racial educational gap, USA, 1940-2000

\begin{tabular}{lll}
\hline Estimation method: pooled OLS & Dependent variables & \\
\cline { 2 - 3 } & High-school gap & Bachelor gap \\
\hline Slaves/population 1860 & $4.404^{* * *}$ & $4.105^{* * *}$ \\
& $(5.36)$ & $(3.56)$ \\
Observations & 258 & 258 \\
$R$-squared & 0.65 & 0.43 \\
\hline
\end{tabular}

Robust $t$ statistics in parentheses. Additional controls: population and dummies for slave states and time. The source of the dataset is Bertocchi and Dimico (2010) ${ }^{* * *} p<0.01$ 
returns for whites. The latter turns out to be well below 1 , consistently with the presence of discrimination. Using this proxy, we do find that racial discrimination contributes to inequality, but to a much lesser degree if compared to the human capital transmission channel. This conclusion is consistent with Fryer (2011), who argues that relative to the twentieth century the relevance of discrimination as an explanation for racial inequalities has declined, since racial differences are greatly reduced when one accounts for educational achievement. We conclude with suggestive evidence that the underlying links between past slavery and current inequality run through the political exclusion of former slaves and the resulting negative influence on the local provision of education for black children.

In a companion investigation also by Bertocchi and Dimico (2012a), my coauthor and I shed further light on the evolution of racial educational inequality across states from 1940 to 2000, extending the results illustrated in Table 6. Despite a gradual reduction of the gap over this period, the evidence shows that the racial gap at the high-school and bachelor level is determined by the initial gap in 1940, which is in turn largely explained by past slavery. The correlation between the racial educational gap in 1940 and the share of slaves over population in 1860 is in fact 0.90 and 0.81 , at the highschool and bachelor level, respectively. Two-stage least-square regressions where slavery is used as an instrument for the initial gap confirm this conclusion. The issue of the excludability of slavery is addressed by instrumenting it with the share of disembarked slaves from the trans-Atlantic slave trade, i.e., accounting for the link between the geographic slave distribution following the Middle Passage and the one prevailing after the Second Middle Passage. We also find that income growth over the same period is negatively correlated with the initial racial gap in education, which suggests that slavery also exerts an indirect effect on growth through the education channel.

In Bertocchi and Dimico (2012b), my coauthor and I extend the analysis of the political implications of slavery using a unique dataset on voting registration by race assembled for the counties in the state of Mississippi in 1896, in the middle of the period that witnesses the restoration of the white elites' supremacy. We show that the disfranchisement measures introduced with the new 1890 state constitution (i.e., the requirement of a poll tax and a literacy test for voting registration) negatively affect the political participation of blacks. However, we also show that the decline starts even earlier, reflecting a process of institutionalization of de facto disfranchisement and thus supporting the fait accompli hypothesis advanced by Key (1949). Black registration is shown to be more limited in the presence of a larger share of black population, which is in turn highly correlated with a larger share of slaves before abolition. This can be explained by the fact that a majority of black voters represents a more serious threat to white supremacy. The paper also shows that restrictions in black political participation affect educational policies in a persistent fashion, consistently with the previously mentioned contributions. Naidu (2012) also contains an analysis of the consequences of the disfranchisement measures introduced in Southern states on political and educational outcomes. Acharya et al. (2016) show that contemporary differences in political attitudes still reflect the intensity of slavery in 1860, with Southern whites more likely to support the Republican party and oppose affirmative action policies in counties more affected by slavery historically. They interpret these results as the long-term consequences of the conservative political attitudes that developed after the Civil War. 
Again with special attention to Mississippi data, Chay and Munshi (2013) focus on the subsequent epoch which, between 1916 and 1930, witnessed the Great Migration of one million of former slaves from the South to the North of the USA. They find that blacks coming from counties characterized by labor-intensive plantation crops represented a disproportionate share of Northern migrants. They attribute this finding to the development of social network externalities that became instrumental in the mobilization process when large coalition of blacks moved together to Northern cities.

As for the case of Africa, the influence of slavery on gender roles and cultural norms has been investigated also for the case of the USA. Mohinyan (1965) argues that the structure of the black family has been undermined by slavery, with broad consequences on crime and the social condition of blacks. Slavery has also been proposed as an explanation for the racial gap in female labor force participation. Boustan and Collins (2014) show that for over a century, that is from 1870 until at least 1980, black women were more likely than white women to participate in the labor force and to hold jobs in agriculture or manufacturing. They also show that differences in observables cannot fully account for this racial gap, which confirms the intuition in Goldin (1977). The latter suggests that female labor force participation reflects a "double legacy" of slavery. A direct effect may have come from the low levels of income and education for blacks, which pushed more black women into the labor market. Moreover, an indirect effect may have come from an intergenerational transmission channel: since black women were forced to work intensively under slavery, African Americans developed different cultural norms about women's work, with consequent long-term effects. Another cultural implication of slavery is examined by Gouda (2013), who shows that the slave share in 1860 is correlated with contemporary violent crime, suggesting that the culture of violence that developed under slavery still exerts a lasting effect.

Beside education, human capital is also shaped by health conditions. The hypothesis that the racial gap in life expectancy may be linked to the slave trades has been advanced by Cutler et al. (2005), who present evidence suggesting that racial differences in sensitivity to salt, a leading and largely hereditary cause of hypertension, may be due to selection during the Middle Passage. Because of intense water loss, the ability to retain salt and hence water substantially increased the chances of survival, which induced slave traders to select captives on the basis of the salt on their skin. Bhalotra and Venkataramani (2012) find that the impact on adult education and labor market outcomes of the reduction in pneumonia in infancy-thanks to the introduction of antibiotic therapies in the 1930s-decreases with the intensity of slavery in 1860 . They interpret this result as a consequence of pre-Civil Rights barriers to realizing returns to human capital investment for blacks born in the South. The genetic resistance to malaria of African slaves has been suggested by Mann (2011) as the reason why slavery developed in the USA, and indeed Esposito (2013) documents a correlation between malaria suitability and the diffusion of slavery as well as slave owners' preferences for slaves more likely to be immune.

To conclude, the evidence for the USA points to a robust influence of past slavery on inequality, while the influence on current income levels is somewhat weaker. The main channel of transmission is to be found in the unequal access to education and the accumulation of human capital for the descendants of slaves. The political mechanism behind the local provision of funding for schools determined an inferior level, both 
qualitatively and quantitatively, for the education inputs accessible for black children, with lingering consequences to the present day.

Despite the fact that the Civil Rights movement and legislation have removed the most visible vestiges of slavery half a century ago, the debate of the consequences of slavery in the USA is still open. Julian L. Simon influentially contributed to it by proposing a calculation of the black reparations bill, which he estimated to amount to about $\$ 58$ billion, i.e., about $7 \%$ of annual GDP (Simon 1971). The awareness that the lingering influence of the history of blacks in America runs through the human capital channel is witnessed by the declared goals of recent federal education programs, from Bush's No Child Left Behind to Obama's Race to the Top, which have aimed at the removal of the racial and ethnic educational gaps that persistently afflict the American society. At the same time, however, the fact that in the USA inequality displays a strong racial component has not been sufficiently emphasized in the recent debate on the long-term evolution of income and wealth inequality, propelled by the book by Piketty (2014). Indeed in his analysis of inequality, Piketty (2014) only very briefly mentions the racial gap in wealth, despite the fact that-as reported by The Economist (2015) - the median white family in 2013 owned net assets almost thirteen times larger than the median black family. Likewise, Putnam (2015) stresses the widening divide in attitudes toward nurturing children within all racial groups, thus shifting the focus from race to class as a driver of differences in educational achievement. He claims that achievement gaps between rich and poor pupils belonging to the same race are now larger than those between races of the same income level. In other words, according to his analysis, the class gap has been growing within each racial group, while the gaps between racial groups have been narrowing. However, his conclusions can be challenged on the ground that they are driven more by the worsening performance of poor whites rather than by the improvement of that of blacks.

\section{Conclusions}

In his book "It's Getting Better All the Time: 100 Greatest Trends of the Last 100 Years" (published posthumously as Moore and Simon 2000), Julian L. Simon listed the decline of slavery and serfdom around the world-from $75 \%$ of the population in 1750 to $10 \%$ in 2000 (figures are from Engerman 1996) - as one of the major achievements of civilization. Nevertheless, the evidence I reported clearly documents the lingering influence of past slavery on contemporary outcomes, both for the sending countries in Africa and the receiving countries in the Americas. This pervasive influence spreads across the economic, institutional, political, and cultural spheres.

African slavery has represented one of the largest-albeit coerced-migration experiences in history. Some of the contributions described in this paper do consider some aspects of its specific link with the analysis of migration. Namely, in Bertocchi et al. (2015), my coauthors and I focus on the link between slave trades and contemporary attitudes toward citizenship acquisition for migrants across African countries. For the USA, in Bertocchi and Dimico (2012a), we look at the association between the distribution of the slaves disembarked along the North-Atlantic coast and the intensity of slavery in 1860, while Chay and Munshi (2013) emphasize the relationship between plantation slavery and the Great Migration. However, a systematic investigation of the 
potential links between African slavery and contemporary migration flows and policies is still lacking, and therefore represents a promising area for future research.

\section{Acknowledgements}

This paper has been prepared for presentation as the Julian Simon Lecture at the 12th IZA Annual Migration Meeting in Dakar in April 2015. I would like to thank conference participants, the editor of this journal and an anonymous referee, for comments and suggestions. I am especially grateful to Arcangelo Dimico, with whom I co-authored many of the papers that are cited in this paper.

Responsible editor: Denis Fougère

\section{Competing interests}

The IZA Journal of Migration is committed to the IZA Guiding Principles of Research Integrity. The author declares that she has observed these principles.

Received: 28 May 2015 Accepted: 1 August 2016

Published online: 28 December 2016

\section{References}

Acemoglu D, Wolitzky A. The economics of labor coercion. Econometrica. 2011;79:555-600.

Acemoglu D, Johnson S, Robinson JA. The colonial origins of comparative development: an empirical investigation. Am Econ Rev. 2001;91:1369-401.

Acemoglu D, García-Jimeno C, Robinson JA. Finding Eldorado: slavery and long-run development in Colombia. J Comp Econ. 2012:40:534-64.

Acharya A, Blackwell M, Sen M. The political legacy of American slavery. J Polit. 2016;78:621-41.

Berlin I. Generations of captivity: a history of African American slaves. Cambridge: Harvard University Press; 2003.

Berlin I. The making of African America: the Four Great Migrations. New York: Viking; 2010.

Bertocchi G. Growth, colonization, and institutional development: in and out of Africa. In: de La Grandville O, editor. Economic growth and development, frontiers of economics and globalization, vol. 11. Bingley: Emerald; 2011. p. 25-41.

Bertocchi G. Slavery, Racial Inequality, and Education. IZA World of Labor. 2015;122:1-10.

Bertocchi G, Canova F. Did colonization matter for growth? An empirical exploration into the historical causes of Africa's underdevelopment. Eur Econ Rev. 2002;46:1851-71.

Bertocchi G, Dimico A. Slavery, education, and inequality, IZA Discussion Paper No. 5329. 2010.

Bertocchi G, Dimico A. The racial gap in education and the legacy of slavery. J Comparative Economics. 2012a;40:581-95. Bertocchi G, Dimico A. De jure and de facto determinants of power: evidence from Mississippi, IZA Discussion Paper No. 6741. 2012b.

Bertocchi G, Dimico A. Slavery, Education, and Inequality, European Economic Review. 2014;70:197-209.

Bertocchi G, Dimico A. The long-term determinants of female HIV infection in Africa: the slave trade, polygyny, and sexual behavior. Mimeo: University of Modena and Reggio Emilia; 2015

Bertocchi G, Guerzoni A. The fragile definition of state fragility. Rivista Italiana degli Economisti. 2011;16:339-56.

Bertocchi G, Guerzoni A. Growth, history or institutions: what explains state fragility in sub-Saharan Africa? J Peace Res. 2012;49:769-83.

Bertocchi G, Strozzi C. International migration and the role of institutions. Public Choice. 2008;137:81-102.

Bertocchi G, Strozzi C. The evolution of citizenship: economic and institutional determinants. J Law Econ. 2010; 53:95-136.

Bertocchi G, Dimico A, Tedeschi GL. Trust and attitudes toward citizenship in sub-Saharan Africa. Mimeo: University of Modena and Reggio Emilia; 2015.

Bhalotra S, Venkataramani A. Shadows of the captain of the men of death: early life health interventions, human capital investments, and institutions. Mimeo: University of Bristol; 2012.

Bobonis GJ, Morrow PM. Labor coercion and the accumulation of human capital. J Dev Econ. 2014;108:32-53.

Bockstette V, Chanda A, Putterman L. States and markets: the advantage of an early start. J Econ Growth. 2002;7: $347-69$.

Boserup E. Women's role in economic development. London: George Allen and Unwin; 1970.

Boustan LP, Collins WJ. The origins and persistence of Black-White differences in women's labor force participation. In: Boustan LP, Frydman C, Margo RA, editors. Human capital in history: the American record. Chicago: University of Chicago Press; 2014. p. 205-41.

Canaday N, Tamura R. White discrimination in provision of Black education: plantations and towns. J Economic Dynamics \& Control. 2009;33:1490-530.

Chay K, Munshi K. Black networks after emancipation: evidence from reconstruction and the Great Migration. Mimeo: University of Cambridge; 2013.

Curtin PD. The Atlantic slave trade: a census. Madison: University of Wisconsin Press; 1969.

Cutler DM, Fryer Jr RG, Glaeser EL. Racial differences in life expectancy: the impact of salt, slavery, and selection. Mimeo: Harvard University; 2005.

Dalton JT, Leung TC. Why is polygyny more prevalent in Western Africa? An African slave trade perspective. Econ Dev Cult Chang. 2014;62:599-632.

David PA, Stampp KM, editors. Reckoning with slavery: critical essays in the quantitative history of American Negro Slavery. New York: Oxford University Press; 1976.

Dell M. The persistent effects of Peru's mining mita. Econometrica. 2010;78:1863-903.

Edlund E, Ku H. The African slave trade and the curious case of general polygyny, MPRA Paper No. 52735. 2011.

Eltis D, Behrendt SD, Richardson D, Klein HS. The Trans-Atlantic slave trade: a database on CD-Rom. New York:

Cambridge University Press; 1999. 
Engerman SL. The extent of slavery and freedom throughout the ages, in the world as a whole and in major subareas. In: Simon JS, editor. The state of humanity. Oxford: Blackwell; 1996. p. 171-7.

Engerman SL, Sokoloff KL. Factor endowments, institutions, and differential growth paths among new world economies: a view from economic historians of the United States. In: Haber S, editor. How Latin America fell behind: essays on the economic histories of Brazil and Mexico, 1800-1914. Palo Alto: Stanford University Press; 1997. p. 260-304.

Esposito E. Side effects of immunities: the African slave trade. Mimeo: University of Bologna; 2013.

Fage JD. Slaves and society in Western Africa, c. 1445 - c. 1700. J African History. 1980;21:289-310.

Fenske J. African polygamy: past and present. Mimeo: University of Oxford; 2013.

Fenske J, Kala N. 1807: Economic shocks, conflict and the slave trade, CSAE Working Paper No. WPS/2014-02. 2014

Fenske F, Kala N. Climate and the slave trade. J Dev Econ. 2015;112:19-32.

Fogel RW, Engerman SL. Time on the cross: the economics of American Negro slavery. New York: W.W. Norton and Co.; 1974.

Frankema E, Jerven M. Writing history backwards or sideways: towards a consensus on African population, 1850present. Econ History Rev. 2014;67:907-31.

Fryer Jr RG. Racial Inequality in the 21st century: the declining significance of discrimination. In: Ashenfelter O, Card D, editors. Handbook of labor economics, vol. 4B. San Diego: North Holland; 2011. p. 855-971.

Gennaioli N, Rainer I. The modern impact of precolonial centralization in Africa. J Econ Growth. 2007;12:185-234.

Goldin C. Female labor force participation: the origin of black and white differences, 1870 to 1880. J Econ Hist. 1977;37:87-108.

Goody J. The character of kinship. Cambridge: Cambridge University Press; 1973.

Gouda M. The long-term effect of slavery on violent crime: evidence from US counties. Mimeo: Philipps-Universität Marburg; 2013.

Hall RE, Jones $\mathrm{Cl}$. Why do some countries produce so much more output per worker than others? Q J Econ. 1999;114:83-116.

Herbst J. States and power in Africa. Princeton: Princeton University Press; 2000.

Johnson M, Lindblad JT, Ross R. Anglo-African trade in the eighteenth century: English statistics on African trade 1699-1808. Leiden: Centre for the History of European Expansion; 1990.

Key VO. Southern politics in state and nation. Knopf, New York: Alfred A; 1949.

Lagerlöf N. Geography, institutions, and growth: the United States as a microcosm. Mimeo: York University; 2005.

Lagerlöf N. Slavery and other property rights. Rev Econ Stud. 2009;76:319-42.

Mann CC. 1493: how the ecological collision of Europe and the Americas gave rise to the modern world. London: Granta Books; 2011.

Manning P. The enslavement of Africans: a demographic model. Can J African Studies. 1981;15:499-526.

Manning P. Slavery and African life. Cambridge: Cambridge University Press; 1990.

Manning P. African population: projections, 1850-1960. In: Ittmann K, Cordell DD, Maddox GH, editors. The demographics of empire: the colonial order and the creation of knowledge. Athens: Ohio University Press; 2010. p. 245-75.

Margo RA. Race and schooling in the South, 1880-1950: an economic history. Chicago: University of Chicago Press; 1990.

Mariscal E, Sokoloff KL. Schooling, suffrage, and the persistence of inequality in the Americas, 1800-1945. In: Haber S, editor. Political institutions and economic growth in Latin America: essays in policy, history, and political economy. Stanford: Hoover Institution Press; 2000. p. 159-218.

Michalopoulos S, Papaioannou E. Pre-colonial ethnic institutions and contemporary African development. Econometrica. 2013;81:113-52.

Mitchener KJ, McLean IW. The productivity of U.S. States since 1880. J Econ Growth. 2003:8:73-114.

Mohinyan DP. The Negro family: the case for national action. Office of Policy Planning and Research. Washington: United States Department of Labor; 1965.

Moore S, Simon JL. It's getting better all the time: 100 greatest trends of the last 100 years. Washington: Cato Institute; 2000.

Murdock GP. Ethnographic atlas. Pittsburgh: University of Pittsburgh Press; 1967.

Musacchio A, Martínez Fritscher A, Viarengo M. Colonial institutions, trade shocks, and the diffusion of elementary education in Brazil, 1889-1930. J Econ Hist. 2014;74:730-66.

Naidu S. Suffrage, schooling, and sorting in the Post Bellum U.S. South, NBER Working Paper No. 18129. 2012.

Nunn N. The long-term effects of Africa's slave trades. Quarterly J Economics. 2008a;123:139-76.

Nunn N. Slavery, inequality, and economic development in the Americas: an examination of the Engerman-Sokoloff Hypothesis. In: Helpman E, editor. Institutions and economic performance. Cambridge: Harvard University Press; 2008b. p. 180

Nunn N, Puga D. Ruggedness: the blessing of bad geography in Africa. Rev Econ and Stat. 2012;94:20-36.

Nunn N, Wantchekon L. The slave trade and the origins of mistrust in Africa. Am Econ Rev. 2011;101:3221-52.

Piketty T. Capital in the twenty-first century. Cambridge: Harvard University Press; 2014.

Putnam RD. Our kids: the American dream in crisis. New York: Simon \& Schuster; 2015.

Ransom RL, Sutch R. One kind of freedom: the economic consequences of emancipation. 2nd ed. New York: Cambridge University Press; 2001

Sacerdote B. Slavery and the intergenerational transmission of human capital. Rev Econ Stat. 2005;87:217-34

Simon JL. The worth today of United States slaves' imputed wages. J Economic Issues. 1971;5:110-3.

Smith JP. Race and human capital. Am Econ Rev. 1984;74:685-98.

Soares RR, Assunção JJ, Goulart TF. A note on slavery and the roots of inequality. J Comp Econ. 2012;40:565-80.

Summerhill W. Colonial institutions, slavery, inequality, and development: evidence from São Paulo, Brazil, MPRA Paper No. 22162. 2010.

Teso $E$. The long-term effect of demographic shocks on the evolution of gender roles: evidence from the trans-Atlantic slave trade. Mimeo: Harvard University; 2014. 
The Economist. The fire and the fuel. 2015.

Thornton J. The slave trade in eighteenth century Angola: effects on demographic structures. Can J African Studies. 1980;14:417-28

Todd E. L'Enfance du Monde, Structures Familiales et Développement. Paris: Seuil; 1984

Wegenast T. Cana, Café, Cacau: agrarian structure and educational inequalities in Brazil. J Iberian and Latin Am Economic History. 2010:28:103-37.

Whatley W. The transatlantic slave trade and the evolution of political authority in West Africa, MPRA Paper No. 44932. 2012a.

Whatley W. The gun-slave cycle in the 18th century British slave trade in Africa, MPRA Paper No. 44492. 2012b.

Whatley W, Gillezeau R. The impact of the transatlantic slave trade on ethnic stratification in Africa. Am Econ Rev. 2011:101:571-6.

Submit your manuscript to a SpringerOpen ${ }^{\oplus}$ journal and benefit from:

- Convenient online submission

- Rigorous peer review

- Immediate publication on acceptance

- Open access: articles freely available online

- High visibility within the field

- Retaining the copyright to your article

Submit your next manuscript at $\gg$ springeropen.com 